\title{
Virulence Factors and Genotypic Characterization of Escherichia coli Isolated from Chickens
}

\author{
A.A.R.Khafagy*, Samah Eid ** and RashaA. Mohammed*** \\ Bacteriology, Mycology and Immunology, Deptartment, Faculty of Vet.Med., \\ Suez Canal University*. Bacteriology Deptartment, Animal Health \\ Research Institute, Dokki, Giza**., Egypt 3Reference Laboratory for quality \\ control on poultry production (RLQP). Animal Health Research Institute, \\ Sharkia Branch, Egypt****.
}

\begin{abstract}
This study assesses the presence of one hundred and fourteen E. coli strains recovered from five hundred chicken examined samples including five hundred heart, five hundred livers and five hundred cloacal swabs with a percentage of $12.8 \%$. E. coli is one of the most common isolates in avian diseases, which causes colibacillosis, or act as a major factor in development of acute respiratory disease causing high losses especially between chickens. In addition to the conventional methods used for isolation and identification of $\mathrm{E}$. coli, PCR is required as rapid, accurate and specific tool for detection of pathogenic $E$. coli and their virulence genes.
\end{abstract}

\section{Introduction}

Escherichia coli is normally found in the digestive tract of poultry and most strains are non-pathogenic. The pathogenic capacity of $\boldsymbol{E}$. coli for chickens to cause significant diarrheal and extraintestinal diseases has been associated with numerous extrinsic and intrinsic bird related factors and condition. The extrinsic factors include environment, exposure to other infectious agents, virulence and duration of exposure. The intrinsic factors affecting susceptibility includes age, rout of exposure and breed or strain of chicken Piercy (1976). Avian colibacillosis is regarded as one of the major causes of morbidity and mortality, associated with heavy economic losses to poultry industry through its association with various disease conditions, either as primary pathogen or as a secondary pathogen Kwon (2008). The symptoms of colibacillosis are non-specific and differ with age, organs involved and concurrent disease. Chickens of all ages are susceptible to colibacillosis but usually young birds are considered more susceptible Barnes (1997) and Gross (1994). It causes a variety of disease syndromes in poultry including yolk sac infection, omphalitis, respiratory tract infection, swollen head syndrome, 
acute colisepticemia, coligranuloma, enteritis, cellulitis and salpingitis. Colibacillosis of poultry is characterized in its acute form by septicemia resulting death and in its subacute form by pericarditis, airsacculitis and peri hepatitis Calnek (1997). PCR technique is capable of identifying the most highly pathogenic E. coli isolates in a flock. JanBen et al. (2001). Based on the fact that virulence varies not only among different species but also among strains of the same species. Thus, numerous studies have been conducted to identify virulence factors of isolated pathogenic E. coli strains Kaipainen et al. (2002); Zaki et al. (2004) and Ewers et al. (2009). Avian pathogenic E.coli for poultry commonly belong to certain serogroups O1, O2, O11, O15, O55, O78, O79 and O111 Gross (1994) and Bopp et al. (2005).The pathogenic and non- pathogenic strains in poultry are differentiated based on the virulence, which has been attributed to various factors including those encoding for adhesions (F1, P, and stg fimbriae, curli,and EA/I), anti-host defense factors

(ompA,iss,lipopolysaccharide, and $\mathrm{K} 1)$, iron acquisition systems (aerobactin, iroproteins, yersiniabactin, and the sit iron acquisition locus), auto transporters (tsh,vat, and aatA), the phosphate transport system, sugar metabolism, the ibeA protein and motility $\boldsymbol{D h o}$ -Moulin(1999).
This study was planned for bacteriological characterization of chicken E. coli isolates and detection of some virulence genes of the isolated strains by using PCR. Therefore, the present study was planned to determine the prevalence and serotypes of avian pathogenic E. coli (APEC) strains in broilers farms in winter and summer seasons in Sharkia Governorate, Egypt and detection of some virulence genes of the isolated strains by using polymerase chain reaction (PCR). Thus, the current study was undertaken to:

1- Isolate $E$. coli from organs and cloacal swabs samples

2- Identifiy E. coli isolates microscopically, biochemically and serologically.

3- Detect toxigenic genes (iss, omp A, pap $\mathrm{C}$, tsh, iro $\mathrm{N}$, eae $\mathrm{A}$, sxt1and sxt2) in E. coli isolates using PCR.

\section{Material and Methods:}

Examination of five hundred samples were collected from different sources in Sharkia province, Egypt. Five hundred samples were collected from (liver, heart and cloacal swabs) of broilers that had died from colibacillosis with typical preceding symptoms like septicemia, respiratory infections and premature death. Samples were aseptically collected in sterile containers and immediately transported in an icebox to the laboratory for further bacteriological examination 
according to Konemann et al. (1997). the technique recommended by Cruickshank et al., (1975) and Quinn et al. (2002) and MOLECULAR DETECTION OF VIRULENCE GENES

$E$. coli isolates were isolated using QIA prep Spin Miniprep Kit (QIAGEN GmbH, Hilden, Germany). Screening for the presence of virulence genes was carried out by PCR amplifications using specific primers and different cycling conditions as previously described Sambrook et al. (1989) The PCR products were tested for positive amplification by agarose gel electrophoresis. For each PCR experiment, appropriate positive and negative controls were included.

\section{Material used for extraction of} DNA

QIAamp DNA Mini Kit Catalogue no.51304

oligonucleotide primers used in cPCR Eight pairs of primers were supplied from metabion (Germany) or Biobasic (Canada).

They have specific sequence and amplify specific products as shown in Table (1).

Material used for Agarose gel electrophoresis (Agarose $1.5 \%$ ) according to Sambrook et al., (1989)

A multi-purpose, high gel strength agarose suitable for a wide range of molecular biology techniques. As it has high gel strength and exclusion limits, multi $\mathrm{AB}$ garose could effectively separate large DNA fragments with reduced running times. This in turn means less band diffusion, a problem often associated with long running times. It was prepared as follow: Agarose 1.5\%

Agarose powder (ABgene) $1.5 \mathrm{~g}$ TBE $100 \mathrm{ml}$

Ethidium bromide solution $10 \mathrm{mg}$ / ml Sambrook et al., (1989)

Ethedium bromide powder (Sigma) $10 \mathrm{mg}$

Sterile DDW $1.0 \mathrm{ml}$

It was mixed and stored covered at $4^{\circ} \mathrm{C}$ It was added to melted agarose to reach a final concentration of 0.1 $0.5 \mu \mathrm{g} / \mathrm{ml}$.

Tris borate EDTA (TBE) electrophoresis buffer (1x) WHO, (2002)

Tris buffer (Fluka) $10.78 \mathrm{~g}$

Boric acid (Fluka) $5.5 \mathrm{~g}$ EDTAdiNA (Winlab) $0.82 \mathrm{~g}$

It was brought up to 1 liter with deionized water, $\mathrm{pH}$ was checked up. If the $\mathrm{pH}$ was out of the range of 8-8.6, a new solution was prepared again.

Any change in ion concentration would affect the migration of the DNA through the gel.

Equipment and apparatuses used in $\mathbf{C P C R}$

Calibrated cylinders, Glass flasks, PCR tubes $0.2 \mathrm{ml}$ capacity, Balance (Scaltec), Microwave (Panasonic), Monochannel micropipette (2-20 $\mu 1)$ (Biohit), Sterile filter tips, Gel casting apparatus (Biometra), T3 Thermal cycler (Biometra), Power supply (Biometra), Type II A biosafety cabinet. (Thermo), Gel 
documentation system (Alpha Innotech), Deionizer (Millipore) and Double distillator (Sanyo).

Extraction of DNA according to a QIAamp DNA Mini Kit Catalogue no.51304 according to the manufacturer's instructions (Qiagen Inc., Valencia, CA, United States)

Preparation of PCR Master Mix according to Emerald Amp GT PCR mastermix (Takara) Code No. RR310A kit as shown in table (2).

Temperature and time conditions of the primers during PCR are shown in table (3).

\section{DNA Molecular weight marker}

The ladder was mixed gently by pipetting up and down. $6 \mu 1$ of the required ladder were directly loaded.

Agarose gel electrophoresis (Sambrook et al., 1989) with modification

Electrophoresis grade agarose (1.5 buffer in a sterile flask, it was heated in microwave to dissolve all granules with agitation, and allowed to cool at $70^{\circ} \mathrm{C}$, then $0.5 \mu \mathrm{g} / \mathrm{ml}$ ethedium bromide was added and mixed thoroughly.

The warm agarose was poured directly in gel casting apparatus with desired comb in apposition and left at room temperature for polymerization.

The comb was then removed, and the electrophoresis tank was filled with TBE buffer. Twenty $\mu 1$ of each uniplex PCR product and and $40 \mu \mathrm{l}$ of each duplex PCR product and negative and positive controls were loaded to the gel. The power supply was $1-5$ volts $/ \mathrm{cm}$ of the tank length. The run was stopped after about 30 min and the gel was transferred to UV cabinet.

The gel was photographed by a gel documentation system and the data was analyzed through computer software.

g) was prepared in $100 \mathrm{ml}$ TBE

Table (1):_Oligonucleotide primers sequences.

\begin{tabular}{|c|c|c|c|}
\hline Gene & $\begin{array}{c}\begin{array}{c}\text { Primer sequence } \\
\left(5^{\prime}-3^{\prime}\right)\end{array} \\
\end{array}$ & $\begin{array}{c}\text { Length of } \\
\text { amplified product }\end{array}$ & Reference \\
\hline \multirow[t]{2}{*}{ iss } & F:ATGTTATTTTCTGCCGCTCTG & \multirow[t]{2}{*}{266 bp } & \multirow[t]{2}{*}{ Yaguchi et al., 2007} \\
\hline & R:CTATTGTGAGCAATATACCC & & \\
\hline \multirow[t]{2}{*}{$T s h$} & F:GGT GGT GCA CTG GAG TGG & \multirow[t]{2}{*}{$620 \mathrm{bp}$} & \multirow[t]{2}{*}{ Delicato et al., 2003} \\
\hline & R:AGT CCA GCG TGA TAG TGG & & \\
\hline \multirow[t]{2}{*}{ iroN } & F:ATC CTC TGG TCG CTA ACT G & \multirow[t]{2}{*}{847 bp } & \multirow[t]{2}{*}{ Ewers et al., 2007} \\
\hline & R:CTG CAC TGG AAG AAC TGT TCT & & \\
\hline \multirow[t]{2}{*}{ papC } & F:TGATATCACGTCAGTAGC & \multirow[t]{2}{*}{$501 \mathrm{bp}$} & \multirow[t]{2}{*}{ Wen-jie et al., 2008} \\
\hline & R:CCGGCCATATTCACATAA & & \\
\hline \multirow[t]{2}{*}{ ompA } & F:AGCTATCGCGATTGCAGTG & \multirow[t]{2}{*}{919 bp } & \multirow[t]{2}{*}{ Ewers et al., 2007} \\
\hline & R:GGTGTTGCCAGTAACCGG & & \\
\hline \multirow[t]{2}{*}{$e a e \mathrm{~A}$} & F:ATG CTT AGT GCT GGT TTA GG & \multirow[t]{2}{*}{248 bp } & \multirow[t]{2}{*}{ Bisi-Johnson et al., 2011} \\
\hline & R:GCC TTC ATC ATT TCG CTT TC & & \\
\hline \multirow[t]{2}{*}{ Stx 1} & F:ACACTGGATGATCTCAGTGG & \multirow[t]{2}{*}{$614 \mathrm{bp}$} & \multirow[t]{4}{*}{ Dipineto et al., 2006} \\
\hline & F: CTGAATCCCCCTCCATTATG & & \\
\hline \multirow[t]{2}{*}{ Stx 2} & F:CCATGACAACGGACAGCAGTT & \multirow[t]{2}{*}{779 bp } & \\
\hline & R:CCTGTCAACTGAGCAGCACTTTG & & \\
\hline
\end{tabular}


Gel Pilot 100 bp ladder (cat. no. 239035) supplied from QIAGEN (USA).

Number of bands: 6 Size range: 100-600 bp.

Gene ruler 100 bp DNA ladder (cat. no. SM0243) supplied from

Fermentas.

Number of bands: 10 Size range: $100-1000 \mathrm{bp}$

Table (2): Preparation of PCR Master Mix:

\begin{tabular}{|c|c|}
\hline Component & Volume/reaction \\
\hline Emerald Amp GT PCR mastermix (2x premix) & $\mathbf{1 2 . 5} \boldsymbol{\mu l}$ \\
\hline PCR grade water & $\mathbf{4 . 5} \boldsymbol{\mu l}$ \\
\hline Forward primer (20 pmol) & $\mathbf{1} \boldsymbol{\mu l}$ \\
\hline Reverse primer (20 pmol) & $\mathbf{1} \boldsymbol{\mu l}$ \\
\hline Template DNA & $\mathbf{6} \boldsymbol{\mu l}$ \\
\hline Total & $\mathbf{2 5} \boldsymbol{\mu l}$ \\
\hline
\end{tabular}

Preparation of $s t x 1$, st $x 2$ multiplex PCR Master Mix

\begin{tabular}{|c|c|}
\hline Component & Volume/reaction \\
\hline Emerald Amp GT PCR mastermix (2x premix) & $\mathbf{2 5} \boldsymbol{\mu l}$ \\
\hline PCR grade water & $\mathbf{1 3} \boldsymbol{\mu l}$ \\
\hline Forward primer (20 pmol) & $\mathbf{1} \boldsymbol{\mu l}$ each \\
\hline Reverse primer (20 pmol) & $\mathbf{1} \boldsymbol{\mu l}$ each \\
\hline Template DNA & $\mathbf{8} \boldsymbol{\mu l}$ \\
\hline Total & $\mathbf{5 0} \boldsymbol{\mu l}$ \\
\hline
\end{tabular}

Table 3: Cycling conditions of the primers during PCR

\begin{tabular}{|c|c|c|c|c|c|c|}
\hline Gene & $\begin{array}{c}\text { Primary } \\
\text { denaturation }\end{array}$ & $\begin{array}{c}\text { Secondary } \\
\text { denaturation }\end{array}$ & Annealing & Extension & $\begin{array}{l}\text { No. of } \\
\text { cycles }\end{array}$ & $\begin{array}{c}\text { Final } \\
\text { extension }\end{array}$ \\
\hline iss & $\begin{array}{l}94^{\circ} \mathrm{C} \\
5 \mathrm{~min} .\end{array}$ & $\begin{array}{c}94^{\circ} \mathrm{C} \\
30 \mathrm{sec} \text {. }\end{array}$ & $\begin{array}{c}54^{\circ} \mathrm{C} \\
30 \mathrm{sec} .\end{array}$ & $\begin{array}{c}72^{\circ} \mathrm{C} \\
30 \mathrm{sec} .\end{array}$ & 35 & $\begin{array}{l}72^{\circ} \mathrm{C} \\
7 \mathrm{~min} .\end{array}$ \\
\hline$t s h$ & $\begin{array}{c}94^{\circ} \mathrm{C} \\
5 \mathrm{~min} .\end{array}$ & $\begin{array}{c}94^{\circ} \mathrm{C} \\
30 \mathrm{sec} .\end{array}$ & $\begin{array}{c}54^{\circ} \mathrm{C} \\
40 \mathrm{sec} .\end{array}$ & $\begin{array}{c}72^{\circ} \mathrm{C} \\
45 \mathrm{sec} .\end{array}$ & 35 & $\begin{array}{c}72^{\circ} \mathrm{C} \\
10 \mathrm{~min} .\end{array}$ \\
\hline iroN & $\begin{array}{l}94^{\circ} \mathrm{C} \\
5 \mathrm{~min} .\end{array}$ & $\begin{array}{l}94^{\circ} \mathrm{C} \\
30 \text { sec. }\end{array}$ & $\begin{array}{c}50^{\circ} \mathrm{C} \\
40 \mathrm{sec} .\end{array}$ & $\begin{array}{c}72^{\circ} \mathrm{C} \\
50 \text { sec. }\end{array}$ & 35 & $\begin{array}{c}72^{\circ} \mathrm{C} \\
10 \mathrm{~min} .\end{array}$ \\
\hline papC & $\begin{array}{c}95^{\circ} \mathrm{C} \\
5 \mathrm{~min} .\end{array}$ & $\begin{array}{c}94^{\circ} \mathrm{C} \\
30 \mathrm{sec} .\end{array}$ & $\begin{array}{c}58^{\circ} \mathrm{C} \\
40 \mathrm{sec} .\end{array}$ & $\begin{array}{c}72^{\circ} \mathrm{C} \\
40 \mathrm{sec} .\end{array}$ & 35 & $\begin{array}{c}72^{\circ} \mathrm{C} \\
10 \mathrm{~min} .\end{array}$ \\
\hline ompA & $\begin{array}{c}95^{\circ} \mathrm{C} \\
5 \mathrm{~min} .\end{array}$ & $\begin{array}{c}94^{\circ} \mathrm{C} \\
30 \mathrm{sec} .\end{array}$ & $\begin{array}{c}58^{\circ} \mathrm{C} \\
40 \mathrm{sec} .\end{array}$ & $\begin{array}{l}72^{\circ} \mathrm{C} \\
1 \mathrm{~min} .\end{array}$ & 35 & $\begin{array}{c}72^{\circ} \mathrm{C} \\
12 \mathrm{~min} .\end{array}$ \\
\hline eaeA & $\begin{array}{c}94^{\circ} \mathrm{C} \\
5 \mathrm{~min} .\end{array}$ & $\begin{array}{c}94^{\circ} \mathrm{C} \\
30 \text { sec. }\end{array}$ & $\begin{array}{c}51^{\circ} \mathrm{C} \\
30 \mathrm{sec} .\end{array}$ & $\begin{array}{c}72^{\circ} \mathrm{C} \\
30 \text { sec. }\end{array}$ & 35 & $\begin{array}{l}72^{\circ} \mathrm{C} \\
7 \text { min. }\end{array}$ \\
\hline $\begin{array}{l}\text { stx1, } \\
\text { stx2 }\end{array}$ & $\begin{array}{c}94^{\circ} \mathrm{C} \\
5 \mathrm{~min} .\end{array}$ & $\begin{array}{c}94^{\circ} \mathrm{C} \\
30 \mathrm{sec} .\end{array}$ & $\begin{array}{c}58^{\circ} \mathrm{C} \\
40 \mathrm{sec} .\end{array}$ & $\begin{array}{c}72^{\circ} \mathrm{C} \\
45 \mathrm{sec} .\end{array}$ & 35 & $\begin{array}{c}72^{\circ} \mathrm{C} \\
10 \mathrm{~min} .\end{array}$ \\
\hline
\end{tabular}




\section{Results \& Discussion:}

Hence, rapid identification of pathogenic E. coli strains and detection of their virulence and resistance genes allow the rapid diagnosis of pathogenic E. coli, so the use of PCR is a powerful molecular biological technique. It provides rapid, reliable results and shows high sensitivity and specificity in the detection some important virulence genes and resistance genes among $E$. coli isolates (Eid and Erfan, 2013).

All isolates were positive for iss gene $(100 \%)$ which had a vital role in E. coli pathogenicity and could be a potential target for developing novel therapeutics and prevention strategies. It gave a characteristic band at 266 bp.as shown in Figure (7).

Another gene associated with bacterial virulence is ompA gene which is responsible for $E$. coli attachment at the host cell were represented in all E. coli isolates $(100 \%)$ as shown in Figure (3), papC gene which is involved in adhesion of pathogenic E. coli to the host cells produced a pronounced band at $501 \mathrm{bp}$ in all tested E. coli isolates except one isolate from fecal swabs as shown in Figure (5). Furthermore; tsh gene which had haemagglutinating activity in APEC produced a pronounced band at $620 \mathrm{bp}$ in all tested E. coli isolates except two isolate from liver and heart samples as shown in Figure (6),
iroN gene which helps $E$. coli to survive in their host aquatic habitat. Amplification of iroN gene produced a pronounced band at $847 \mathrm{bp}$ in all tested E. coli isolates except three isolate $(63 \mathrm{H}, 82 \mathrm{H}$ and 75 LV) as shown in Figure (4). additional factors that contribute to virulence including intimin (encoded by the eae gene), an outer membrane protein involved in the attachment of $E$. coli to the enterocyte with amplican sizes 248 bp as shown in Figure (2)

Besides Shiga toxins stx 1 and stx 2 not found as shown in Figure (1)

Our results confirmed the presence of virulence genes including iss gene, ompA, papC, tsh, iro $\mathrm{N}$, and eae gene in chickens Table (4).

Also (Dutta et al., 2011) collected 15 strains were analyzed by PCR and detect stx 1 , stx 2 and eae A genes. (Parreira and Gyles, 2002) found $s t x 1$ and stx 2 genes in E. coli isolated from avian samples. (Zakeri, 2014) detected eaeA gene in $E$. coli isolated from chicken samples.

Absence of STEC stx 1 and stx 2 gene which get in parallel with Farooq et al., (2009) and Wani et al., (2004) Similarly, Schroeder et al., (2003) could not isolate STEC from retail chicken and turkey obtained from Washington and Kobayashi et al. (2002) did not observe STEC in fecal samples from 199 broiler chickens in Finland. The detection of STEC in chicken was in contrast with $\boldsymbol{E} \boldsymbol{l}$ - 
Jakee et al. (2012) who detected stx 2 by percentage $41.67 \%$.

Concerning to examination of $E$. coli isolates for the presence of Intimin gene, results detected 2out of $12 \mathrm{E}$. coli. These findings were nearly agreed with those obtained from (Dutta et al., 2011) who detected eaeA in $4 \mathrm{E}$. coli strains out of 10 isolates and (El-Jakee et al., 2012) who detected eaeA in 5 E. coli strains out of 12 .

\section{stx 1 and $s t x 2$ genes}

lanes (1-12) represent the tested strains, PCR failed to detect St $x 1$ and st $x 2$ genes in tested isolates. positive control (Lane. pos) and negative control (Lane. neg).

positive controls represented by field sample that were previously confirmed to be positive by PCR for Stx 1 and Stx 2 genes in Reference laboratory for veterinary quality control on poultry production, Animal health research institute.

negative controls represented by buffer without DNA.

\section{eae $A$ gene}

lanes (1-12) represent the tested strains, Lanes 2,7 E. coli isolate (code

No.

$22 \mathrm{H}$ and $73 \mathrm{LV}$ ) showed eaeA gene positive PCR products

positive control (Lane. pos) and negative control (Lane. neg).

positive controls represented by field sample that were previously confirmed to be positive by PCR for Stx 1 and Stx2 genes in Reference laboratory for veterinary quality control on poultry production, Animal health research institute.

negative controls represented by buffer without DNA

\section{ompA gene}

lanes (1-12) represent the tested strains, Lanes 1,2,3,4,5,6,7,8,9,10,11,12 E. coli isolates (code No. 1H, $22 \mathrm{H}, 63 \mathrm{H}$, $82 \mathrm{H}, 42 \mathrm{LV}, 72 \mathrm{LV}, 73 \mathrm{LV}, 75 \mathrm{LV}$, $52 \mathrm{~F}, 76 \mathrm{~F}, 8 \mathrm{~F}, 95 \mathrm{~F}$ ) showed ompA gene positive $\mathrm{PCR}$ product positive control (Lane. pos) and negative control (Lane. neg).

\section{IroN gene}

lanes (1- 12) represent the tested strains, Lanes 1,2, 5,6,7, 9,10,11,12 E. coli isolates (code No. 1H, 22 H, 42 LV, 72 LV, 73 LV, 52 F, 76 F, 8F, 95 F) showed IroN gene positive PCR product. while line number $(3,4,8)$ (code No. $63 \mathrm{H}, 82 \mathrm{H}, 75 \mathrm{LV})$ were negative.

positive control (Lane. pos) and negative control (Lane. neg)

\section{papC gene}

lanes (1- 12) represent the tested strains, Lanes 1,2,3,4,5,6,7,8, $10,11,12$ E. coli isolates (code No. $1 \mathrm{H}, 22 \mathrm{H}, 63 \mathrm{H}, 82 \mathrm{H}, 42 \mathrm{LV}, 72$ LV, 73 LV, 75 LV, 76 F, 8F, 95 F) showed PapC gene positive PCR product. while lane number (9) (code No. 52F) was negative. positive control (Lane. pos) and negative control (Lane. neg)

\section{tsh gene}

lanes (1- 12) represent the tested strains, Lanes 1,2,3 ,5,6,7, 9,10,11,12 E. coli isolates (code No. 1H, $22 \mathrm{H}, 63 \mathrm{H}, 42 \mathrm{LV}, 72 \mathrm{LV}, 73$ 
LV, 52 F, 76 F, 8F, 95 F) showed Tsh gene positive PCR product positive.while lane number $(4,8)$ (code $82 \mathrm{H}$ and $75 \mathrm{LV}$ ) were negative.

Positive control (Lane. pos) and negative control (Lane. neg)

iss gene

lanes (1-12) represent the tested strains, Lanes 1,2,3,4,5,6,7,8,9,10,11,12 E. coli isolates (code No. $1 \mathrm{H}, 22 \mathrm{H}, 63 \mathrm{H}$, $82 \mathrm{H}, 42 \mathrm{LV}, 72 \mathrm{LV}, 73 \mathrm{LV}, 75 \mathrm{LV}$, $52 \mathrm{~F}, 76 \mathrm{~F}, 8 \mathrm{~F}, 95 \mathrm{~F})$ showed iss gene positive $\mathrm{PCR}$ product. positive control (Lane. pos) and negative control (Lane. neg)

$E$. coli is one of the most common isolates in avian diseases, which causes colibacillosis, or act as a major factor in development of acute respiratory disease causing high losses especially between chickens. In addition to the conventional methods used for isolation and identification of $\mathrm{E}$. coli, PCR is required as rapid, accurate and specific tool for detection of pathogenic E. coli and their virulence genes.

From the current study, the following points could be concluded:

Bacterial examination confirmed cases of colibacillosis from which 114 E. coli strains were isolated.

$\square \square$ All isolates had characteristic biochemical features of $E$. coli.

PCR technique leads to an early diagnosis on the pathogenicity of APEC strains, reducing the time of 3-7 days to achieve by conventional techniques to maximum 24 hours.

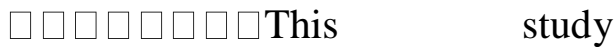
confirmed that E. coli is known as one of the most important pathogenic agents causing disease in poultr. The pathogenicity of the strain is caused by presence of at least six virulence genes as ompA (outer membrane protein) gene, iss gene, papC gene, tsh gene, iroN gene and eaeA (intimin or E. coli attaching and effacing) gene

\section{stx 1 and $s t x 2$ genes}

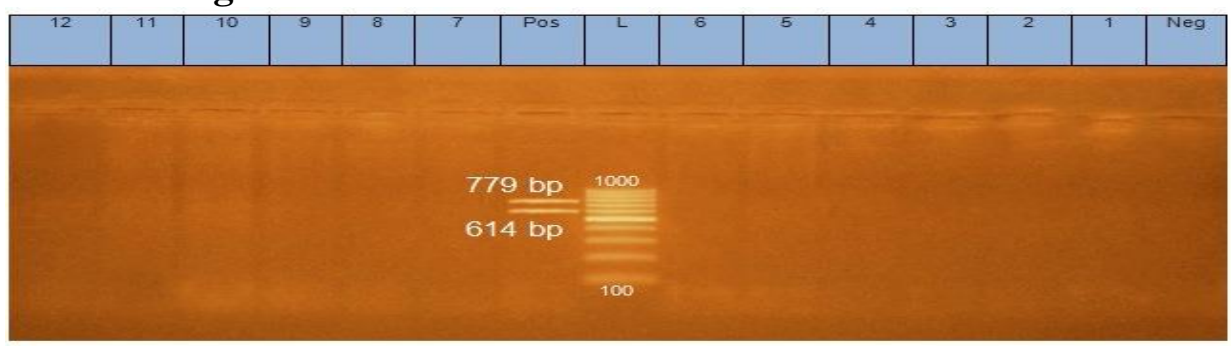

Figure (1): Electrophoretic pattern of the PCR products of stxl and stx2 genes of E. coli

Stx 1 at (614 bp) and stx 2 at (779 bp) genes Lane L: Ladder 100 bp (1001000), 
eae $\mathrm{A}$ gene

\begin{tabular}{|l|l|l|l|l|l|l|l|l|l|l|l|l|l|l|}
112 & 11 & 10 & 9 & 8 & 7 & Pos & L & 6 & $100^{5}$ & 4 & 3 & 2 & 1 & Neg \\
\hline
\end{tabular}

Figure (2): Electrophoretic pattern of the PCR products of eaeA gene of $E$. coli. eae A gene at (248bp). Lane L: Ladder 100 bp (100-600), .ompA gene

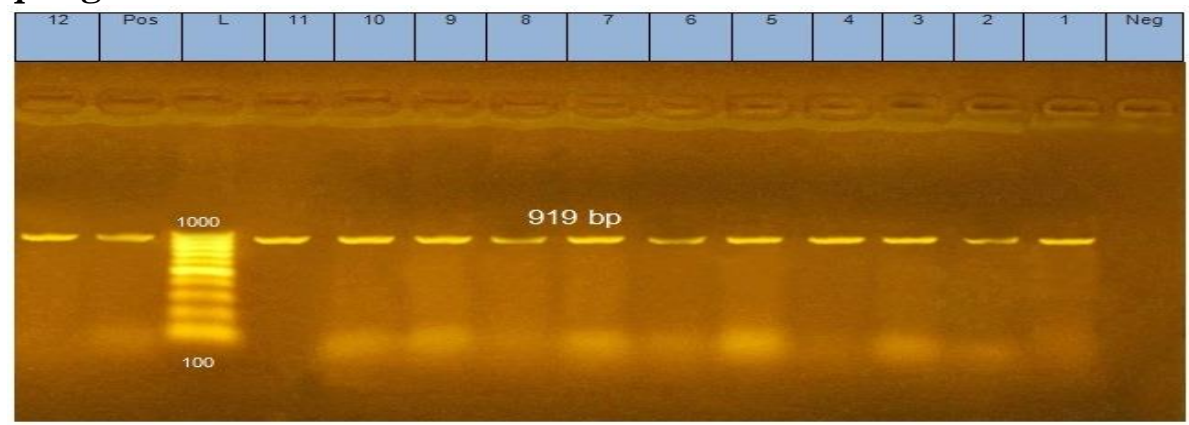

Figure (3): Electrophoretic pattern of the PCR products of ompA gene of $E$. coli. ompA gene at (919bp). Lane L: Ladder 100 bp (100-1000), IroN gene

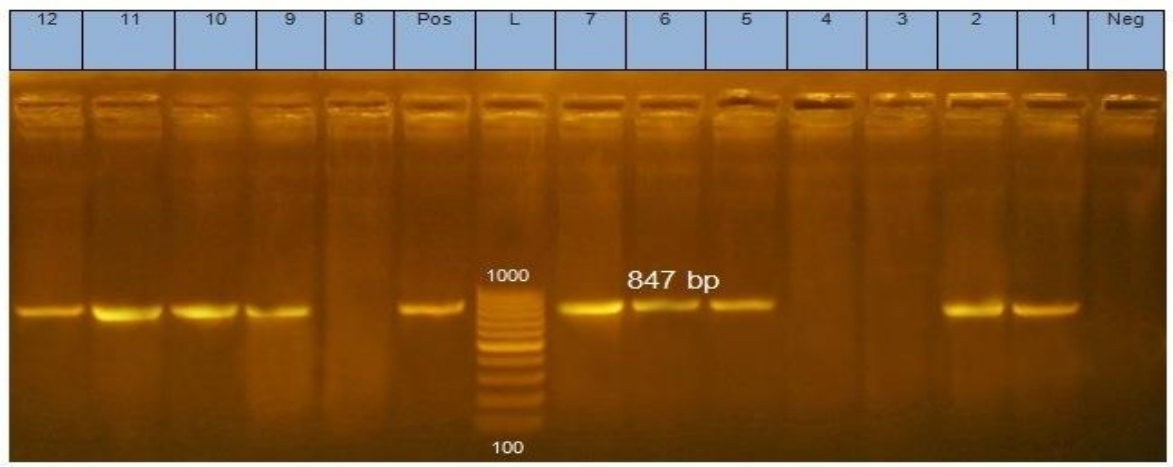

Figure (4): Electrophoretic pattern of the PCR products of iroN gene of $E$. coli. iroN gene at (847bp). Lane L: Ladder 100 bp (100-1000),

\section{papC gene}
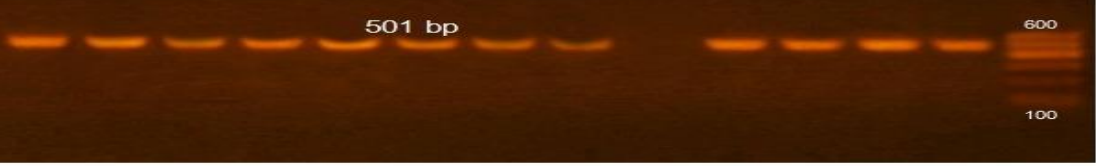
Figure (5): Electrophoretic pattern of the PCR products of papC gene PapC gene at (501bp). L: Ladder 100 bp (100-600),

\section{tsh gene}

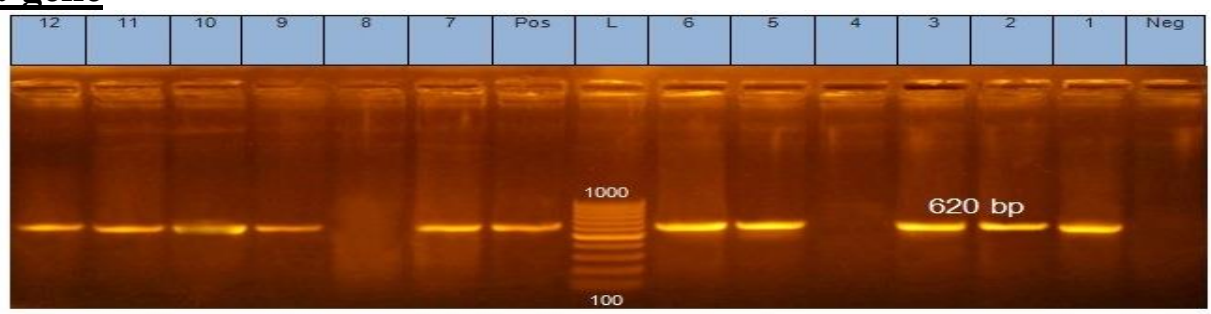

Figure (6): Electrophoretic pattern of the PCR products of tsh gene of E. coli tsh gene at (620bp). Lane L: Ladder 100 bp (100-1000),

\section{iss gene}

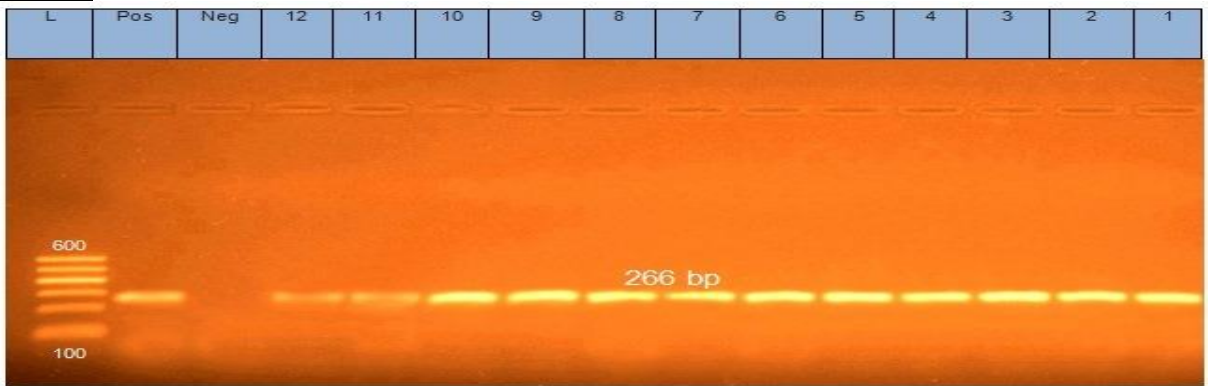

Figure (7): Electrophoretic pattern of the PCR products of iss gene of E. coli iss gene at (266bp). Lane L: Ladder 100 bp (100-600),

Table (4): Distribution of virulence genes detected in E. coli strains isolated from both liver \&heart blood and fecal swabs samples

\begin{tabular}{|c|c|c|c|c|c|c|c|c|c|c|c|}
\hline Sample & ID & Serotype & Type & stx 1 & stx 2 & $e a e \mathbf{A}$ & ompA & iro $\mathrm{I}$ & $\operatorname{apC}$ & $t s h$ & iss \\
\hline $1 \mathrm{H}$ & 1 & O44 : H11 & EPEC & - & - & - & + & + & + & + & + \\
\hline $22 \mathrm{H}$ & 2 & $\mathrm{O} 78: \mathrm{H} 4$ & EPEC & - & - & + & + & + & + & + & + \\
\hline $63 \mathrm{H}$ & 3 & O91 : H11 & EHEC & - & - & - & + & - & + & + & + \\
\hline $82 \mathrm{H}$ & 4 & $\mathrm{O} 1: \mathrm{H} 11$ & EPEC & - & - & - & + & - & + & - & + \\
\hline $42 \mathrm{LV}$ & 5 & O128: H6 & ETEC & - & - & - & + & + & + & + & + \\
\hline $72 \mathrm{LV}$ & 6 & O91 : H11 & EHEC & - & - & - & + & + & + & + & + \\
\hline $73 \mathrm{LV}$ & 7 & $\mathrm{O} 2: \mathrm{H} 2$ & EPEC & - & - & + & + & + & + & + & + \\
\hline $75 \mathrm{LV}$ & 8 & O125 & ETEC & - & - & - & + & - & + & - & + \\
\hline 52F & 9 & $\mathrm{O} 2: \mathrm{H} 7$ & EPEC & - & - & - & + & + & - & + & + \\
\hline $76 \mathrm{~F}$ & 10 & $\mathrm{O} 78: \mathrm{H} 4$ & EPEC & - & - & - & + & + & + & + & + \\
\hline $8 \mathrm{~F}$ & 11 & O121: H6 & EHEC & - & - & - & + & + & + & + & + \\
\hline $95 \mathrm{~F}$ & 12 & $\mathrm{O} 78: \mathrm{H} 4$ & EPEC & - & - & - & + & + & + & + & + \\
\hline
\end{tabular}


References

Barnes, H. J. and Gross, W. B. (1997): Colibacillosis. pp. 131141. In: Diseases of Poultry, 10th ed.

Bisi-Johnson, M.A.; Obi, C.L.; Vasaikar, S.D.; Baba, K.A. and Hattori, T. (2011): Molecular basis of virulence in clinical isolates of Escherichia coli and Salmonella species from a tertiary hospital in the Eastern Cape, South Africa. Gut Pathogens 2011, 3:9.

Bopp, C. A.; Brenner, F. W.; Wells, J. G. and Strockbine, N. A. (2005): Escherichia, Shigella and Salmonella. In: Manual of Clinical Microbiology. (Murray, P. R., Baron, E. J. Pfaller, M. A. Tenover, F. C. Yolken, R. H. Eds.). American Society for Microbiology, Washington, DC. 459- 474.

Calnek, B.W., H.J. Barnes, C.W. Beard, L.R. McDougald and Y.M. Saif, (1997): Diseases of Poultry. Iowa State University Press, Ames, IA., USA., Pages: 1080.

Cruickshank, R.; Dugi, J. P.; Marmion, B. R. and swain, $\mathbf{R}$. H. A. (1975): Medical Microbiology, 12th Ed., Living stone, London, New York, 812-825.

Delicato, E.R.; de Brito, B.G.; Gaziri , L.C.J. and Vidotto, M.C. (2003): Virulence-associated genes in Escherichia coli isolates from poultry with colibacillosis. Veterinary Microbiology 94 (2003) 97-103.

Dho-Moulin, M. Fairbrother, J. M. (1999):
Avian pathogenic E. coli (APEC). Vet. Res., 30: 299-316.

Dipineto, L.; Santaniello, A.; Fontanella, M.; Lagos, K.; Fioretti, A. and Menna, L. F. (2006): Presence of Shiga toxinproducing $E$. coli $\mathrm{O} 157: \mathrm{H} 7$ in living layer hens. Letters in Applied Microbiology. 43(3): 293-295.

Dutta, T. K.; Roychoudhury, P.; Bandyopadhyay, S.; Wani, S. A. and Hussain, I. (2011): Detection \& characterization of Shiga toxin- producing E. coli (STEC) \& enteropathogenic E. coli (EPEC) in poultry birds with diarrhea. Indian J. Med. Res., 133, pp. 541-545.

Eid S A S and Erfan A M (2013): Characterization of E. coli associated with high mortality of poultry flocks. Assiut Vet. Med. J., 59 (139).

El-Jakee, J. K.; Mahmoud, R. M.; Samy, A. A.; El-Shabrawy, M. A.; Effat, M. M. and Gad El-Said, W. A. (2012): Molecular Characterization of E. coli Isolated from Chicken, Cattle and Buffaloes. International Journal of Microbiological Research, 3(1): 6474.

Ewers, C.; Li, G.; Wilking, H.; Kiebling, S.; Alt, K.; Antáo, E.M.; Laturnus, C.; Diehl, I.; Glodde, S.; Homeier, T.; Böhnke, U.; Steinrück, H.; Philipp, H.C.; Wieler, L.H. (2007): Avian pathogenic, uropathogenic, and newborn meningitis-causing Escherichia coli and How closely related are they?. International 
Journal of Medical Microbiology 297 (2007) 163-176.

Ewers, C.; Antao, E. M.; Diehl, I.; Philipp, H. C. and Wieler, L. H. (2009): Intestine and environment of the chicken as reservoirs for extraintestinal pathogenic E. coli strains with zoonotic potential. Appl. Environ. Microbiol., 75: 184192.

Farooq, S.; Hussain, I.; Mir, M. A.; Bhat, M. A. and Wani, S. A. (2009): Isolation of atypical enteropathogenic E. coli and Shiga toxin 1 and 2 f- producing $E$. coli from avian species in India. Lett. Appl. Microbiol., 48(6): 692-697.

Gross, W. G. (1994): Diseases due to $E$. coli in poultry, pp. 237-259. In Gyles, C. L. (ed.), E. coli in domestic animals and humans. $\mathrm{CAB}$ International, Wallingford, United Kingdom.

JanBen, T.; Schwarz, C.; Preikschat, P.; Voss, M.; Philipp, H. C. and Wieler, L. H. (2001): Virulence-associated genes in avian pathogenic E.coli (APEC) isolated from internal organs of poultry having died from colibacillosis". Inter. J. Med. Microbiol., 291(5): 371-378.

Kaipainen, T., Pohianvitra, T., Sphigel, $\mathbf{N}$ and Pelkonen, $\mathrm{S}$. (2002): Virulence factors of E.coli isolated from bovine clinical mastitis. J. Vet. Microbiol., 26 (1): 37-46.

Kobayashi, H.; Pohjanvirta, T. and Pelkonan, S. (2002): Prevalence and characteristics of intimin and Shiga toxin-producing E.coli from gulls, pigeons and broilers in Finland. Journal of Veterinary Medical Science 64: 1071-1073.

Konemann, E. W.; Allen, S. D.; Janda, W. M.; Schreckenberger, P. C. and Winn, W. C. (1997): Color atlas and textbook of diagnostic microbiology. 5th Ed. J. B. Lippincott Co., 1296- 1395.

Kwon, S. G.; Cha, S. Y.; Choi, E. J.; Kim, B.; Song, H. J. and Jang, H. K. (2008): Epidemiological prevalence of avian pathogenic E.coli differentiated by multiplex PCR from commercial chickens and hatchery in Korea. Journal of Bacteriology and Virology. Volume 38. No. 4. pp.

179-188.

Parreira, V. R. and Gyles, C. L. (2002): Shiga toxin genes in avian E.coli.Vet. Microbiol., 87(4), 341352.

Piercy, D.W.T. and West, B. (1976) : Experimental Escherichia coli infection in broiler chickens: Course of the disease induced by inoculation via the air sac route. J. Comp. Pathol., 86: 203-210.

Quinn, P.J.;Markey, B.K.; Carter, M.E.; Donnelly, W.J.C. and Leonard, F.C. (2002): Veterinary Microbiology and microbial diseases. Blackwell science, UK.

Sambrook J, Fritsch E F and Maniatis T (1989): Molecular cloning: a laboratory manual. $2^{\text {nd }}$ Edition.Cold spring harbor, N.Y.: Cold spring harbor laboratory. 
Schroeder, C. M.; White, D. G.; Ge, B.; Zhang, Y.; McDermott, P. F.; Ayers, S.; Zhao, S. and Meng, J. (2003): Isolation of antimicrobial resistant $E$. coli from retail meats purchased in Greater Washington, DC, USA. International Journal of Food Microbiology 85: 197-202.

Wani, S. A.; Samanta, I.; Bhat, M. A. and Nishikawa, Y. (2004): Investigation of Shiga toxinproducing E.coli in avian species in India. Letters in Applied Microbiology, 39: 389-394.

Wen-jie J, Zhi-ming Z, Yong-zhi $Z$, Ai-jian Q, Hong-xia S, Yuelong L, Jiao W, and Qian-qian W. (2008): Distribution of VirulenceAssociated Genes of Avian Pathogenic Escherichia coli Isolates in China. Agricultural Sciences in China, 7(12): 1511-1515.

WHO (2002): World Health organization. Department of communicable diseases surveillance and response.

Yaguchi, K.; Gitano, T.; Oshawa, R.; Kawano, M.; Kokumai, N.; Kaneshige, $\quad$ T.; $\quad$ Noro,T.; Mabuchi, K. and Shimizu, Y.(2007): Virulence Factors of Avian Pathogenic Escherichia coli Strains Isolated from Chickens with Colisepticemia in Japan. Avian Dis. 2007 Sep;51(3):656-62.

Zakeri, A. (2014): Detection of the eaeA Gene in E. coli Isolated from Broiler Chickens by Polymerase Chain Reaction. Iranian Journal of Applied Animal Science. Volume: 4; NO. 2: 417- 420.

Zaki, E., Riad, E., Sobhy, N. (2004): Correlation between E.coli serotypes isolated from buffalo mastitis milk with different virulence patterns. J. Egypt Vet. Med. Assoc., 64 (3): 53-63. 


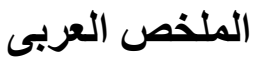

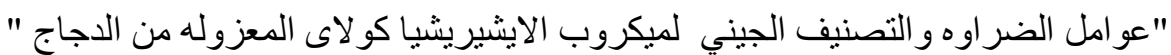

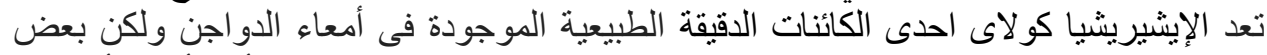

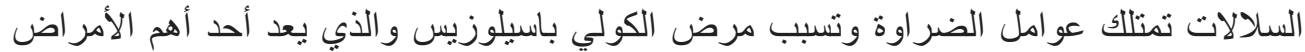

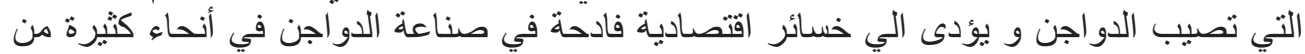

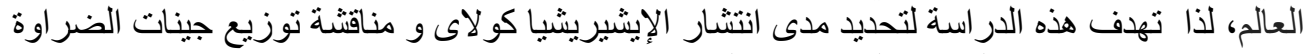

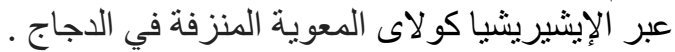

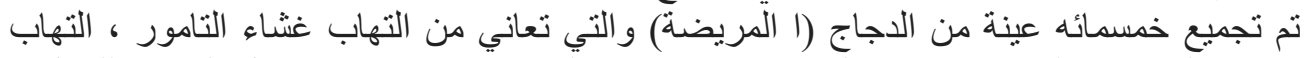

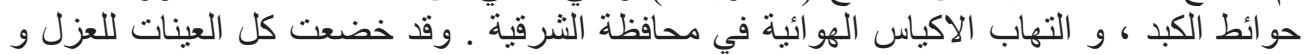

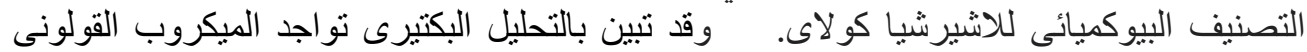

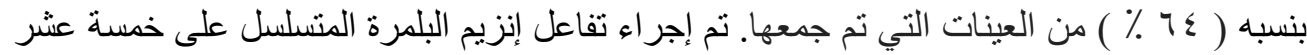

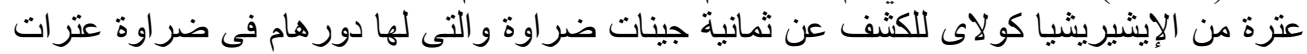

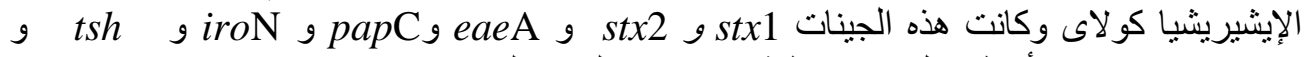
و و ompA eae A gene 248 bp, ompA gene 919 bp, iroN gene 847 bp, papC gene 501 bp, $t$ sh gene $620 \mathrm{bp}$ and iss gene $266 \mathrm{bp}$

بينما كلا من stx1 و stx2 سلبي في كل العينات .وقد اوضحت الدر استات ان نسبة الكثف عن كلا

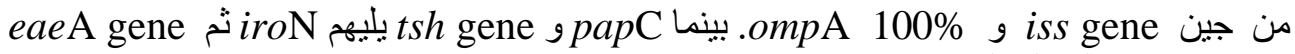

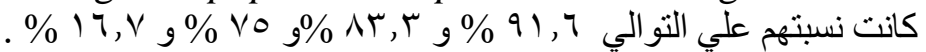

